\title{
The relationship between personal responsibility and pro-environmental intention in high schools' students
}

\author{
Ahsanul Akhsan Dasi a,1, ${ }^{,}$, Mieke Miarsyah b,2, Rusdi b,3 \\ a Department of Biology Education, Faculty of Mathematics and Science, Universitas Negeri Jakarta, Jl. Pemuda No.10, RT.8/RW.5, Rawamangun, \\ Pulo Gadung, East Jakarta City, the Special Capital Territory of Jakarta (DKI, Jakarta) 13220, Indonesia \\ ${ }^{b}$ Department of Biology, Faculty of Mathematics and Science, Universitas Negeri Jakarta, Jl. Pemuda No.10, RT.8/RW.5, Rawamangun, \\ Pulo Gadung, East Jakarta City, the Special Capital Territory of Jakarta (DKI, Jakarta) 13220, Indonesia \\ ahsanulakhsandasi@gmail.com*; ${ }^{2}$ mmiarsyah@unj.ac.id; ${ }^{3}$ rusdibioma@yahoo.com \\ * corresponding author
}

\section{ARTICLE INFO}

\section{Article history}

Received November 23, 2018

Revised February 04,2019

Accepted February 23, 2019

Published March 11, 2019

\section{Keywords}

Personal responsibility

Pro-environmental intention

Problem solving

\section{ABSTRACT}

The role of personal responsibility is important to foster a pro-environmental intention can change students' pro-environmental behavior. This study was aimed to analyze the relationship between personal responsibility and pro-environmental intention in XI-MIPA students at SSHS of 8 Makassar, South Sulawesi. This study used a quantitative approach with a descriptive method of correlation techniques. Partisipants for study were 120 students. Data collection used non-test instruments. Analysis of research data used a regression model test $(a=0.05)$ and coefficient test with Pearson Product Moment test $(\alpha=0.05)$. The results showed that there was a positive relationship between personal responsibility and pro-environmental intention. Students who have a high personal responsibility have several advantages, namely (1) can learned how to respect the rights and feelings of others, decide their own desires and the importance of being responsible; (2) able to become independent learners, able to play an active role in learning and their desires more responsibly, and (3) can learn how to respect the rights and feelings of others, decide their own desires and the importance of being responsible.

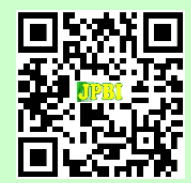

Copyright @ 2019, Dasi et al This is an open access article under the CC-BY-SA license

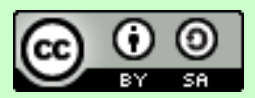

How to cite: Dasi, A. A., Miarsyah, M., \& Rusdi, R. (2019). The relationship between personal responsibility and pro-environmental intention in high schools' students. JPBI (Jurnal Pendidikan Biologi Indonesia), 5(1), 17-22. doi: https://doi.org/10. 22219/jpbi.v5i1.7117

\section{INTRODUCTION}

Changes in ecosystems are caused by human activities, climate change, habitat changes (changes in land use and physical adjustment of natural resources) (Bellard, Bertelsmeier, Leadley, Thuiller, \& Courchamp, 2014; Fedele, Locatelli, Djoudi, \& Colloff, 2018; Kanianska, 2016; Rechkemmer \& Von Falkenhayn, 2009; Seebacher \& Franklin, 2012), population changes, over-exploitation, technological change, and pollution (Keshavarz \& Karami, 2016). Various environmental problems pose a threat to the environment, including global warming, urban air pollution, lack of water, environmental noise, and loss of biodiversity (Anand, 2013; Ashurst, Hargitt, \& Palmer, 2017; Ernst, Blood, \& Beery, 2015; Hasnat, Kabir, \& Hossain, 2018; Sadhu, Garg, \& Kumar, 2018; Steg \& Vlek, 2009; United Nations Environment Programme, 2017). Many of these problems are 
rooted in human behavior and thus can be managed by changing relevant behaviors so as to reduce environmental impacts (Aunger \& Curtis, 2016; Bornstein, Hahn, \& Haynes, 2011; Hope \& Jones, 2014; Kollmuss \& Agyeman, 2002; Martin, Maris, \& Simberloff, 2016; Michie, West, Sheals, \& Godinho, 2018; Steg \& Vlek, 2007, 2009).

Problem solving for the environment can be done by the community component as well as personally (Harris, 2019; Johnson et al., 2007; Zastrow, Kirst-Ashman, \& Hessenauer, 2019). One effort that can be done to solve environmental problems is in the form of growing the pro-environmental intention that has an impact on behaviour (Bronfman, Cisternas, López-Vázquez, De la Maza, \& Oyanedel, 2015; Curtis, Reid, \& Reeve, 2014; Kinzig et al., 2013; Wray-Lake, Flanagan, \& Osgood, 2010). Hines, Hungerford, and Tomera developed a model of responsible environmental behavior. In their model, the pro-environmental responsible is influenced by personality factors. One of the personality factors is personal responsibility (Pan, Chou, Morrison, \& Lin, 2018).

From the point of view of psychology, responsibility can be defined as the limitation of self-chosen individuals relate to taking action depending on how it will affect others (Slavoljub, Dragica, Zorica, Zivkovic, \& Sladjana, 2015). The existence of personal responsibility towards the environment, students can change the environment to be cleaner and safer. Responsibility can be regarded as an individual quality, which is reflected in the realization and emotional experience needed to do every important job for everyone, as well as one's readiness to realize responsible behavior (Dementiy \& Grogoleva, 2016).

Personal responsibility is most commonly understood as accepting responsibility for its own actions, or lack of consequences (Mergler \& Patton, 2007; Pickard, 2014). Personal Responsibility is the ability to regulate one's own thoughts, feelings, and behaviors, along with a willingness to be responsible for choices made based on the social and personal results (Joshi \& Rahman, 2015; Manstead, 2018; Mergler, 2008; Pan et al., 2018). Personal Responsibility is defined as the belief that someone is the ruler of his life, aware of his choices and goals and is willing to demand accountability for his behavior and get the consequences (Bennet, 2017; Boysen, 2013; Mergler \& Shield, 2016).

The Hines model explains that intention to act is influenced by ability, knowledge and personality factors. In the model, locus of control is in personality factors along with attitudes and personal responsbility. Based on previous exposure, personal responsibility is one of the factors that influence students' pro-environmental intention. Therefore, research is needed on the relationship between personal responsibility and proenvironmental intention.

\section{METHOD}

This study used multiple correlational designs. This study used a quantitative approach with a descriptive method of correlation techniques. The location of study was in students of XI-MIPA at State Senior High School (SSHS) of 8 Makassar, South Sulawesi. Participants for the study were 120 students (valid responses). Sample was based on multistage random sampling technique. Data collection used non-test instruments. The survey questionnaire was divided into two sections: personal responsibilty and pro-environmental intention were 5point likert scales from 5 (very accurate) to 1 (not accurate).

Procedure after determining the variables and objectives of the study, researchers conducted a study use non-test instrument in the form of a questionnaire. The results of the questionnaire about personal responsibility will be related to the results of the questionnaire about students' pro-environmental intention. The research was conducted in July 2018.

Analysis of research data used two tests, the prerequisite test; normality test used kolmogorov-smirnov test and homogeneity test used levene test and hypothesis test; test regression model $(a=0.05)$ and the correlation coefficient test with Pearson product moment test $(\alpha=0.05)$.

\section{RESULTS AND DISCUSSION}

The data are presented in Table 1 (Data for each variable), Table 2 (Regression coefficient test results), Table 3 (Pearson product moment correlation test), and Table 4 (Determination coefficient $\left(\mathrm{R}^{2}\right)$ test results). Data for the description of each of the followed variables shows the average, median, standard deviation, sample variation, range, maximum score and minimum score.

Based on the data obtained a significance value that is smaller than $\alpha(0.05)$ which is 0.027 , means that the regression coefficient is significant. The regression equation model formed is $\hat{Y}=61,910+0,191 \mathrm{X} 2$. The calculated significance level is smaller than the significance level of the test set, which is $0.027<0.05$, the model of the relationship between the two variables was linear. Based on these equations, it can be interpreted if 
there is an increase of 1 score of personal responsibility then it will be followed by an increase in proenvironmental intention of 0.191 in the constant 61.910 through the regression model $\hat{Y}$.

The correlation analysis test uses the Pearson Product Moment test. Based on the correlation table (Table 3 ), it is known that the correlation coefficient between personal responsibility and pro-environmental intention is 0.202 , that there is a positive correlation, also obtained a significance value that is smaller than alpha, which is $0.027<0.05$, which means that there is a significant relationship between personal responsibility and proenvironmental intention.

Table 1. Data for each variable

\begin{tabular}{lcc}
\hline & Statistics & \\
\hline Data Description & $P \boldsymbol{R}^{*}$ & $\boldsymbol{P I}^{*}$ \\
\hline Mean & 82.68 & 77.10 \\
Std. Deviation & 10.72 & 10.83 \\
Variance & 114.92 & 117.38 \\
Range & 54 & 42 \\
Minimum & 45 & 51 \\
Maximum & 99 & 93 \\
Sum & 9922 & 9252 \\
$\mathrm{~N}$ & 120 & 120 \\
${ }^{*} P R=$ Personal Responsibility, PEl= Pro-Environmental Intention &
\end{tabular}

Table 2. Regression coefficient test results

\begin{tabular}{|c|c|c|c|c|c|c|}
\hline & \multirow{2}{*}{ Model } & \multicolumn{2}{|c|}{ Unstd. Coef } & \multirow{2}{*}{$\begin{array}{l}\text { Std Co. } \\
\text { Beta }\end{array}$} & \multirow{2}{*}{$t$} & \multirow{2}{*}{ Sig. } \\
\hline & & $\bar{B}$ & Std. E & & & \\
\hline \multirow{2}{*}{1} & (Ctnt) & 61.910 & 6.862 & & 9.021 & .000 \\
\hline & $\mathrm{pr}$ & .191 & .086 & .202 & 2.236 & .027 \\
\hline
\end{tabular}

a. Dependent Variable: pro-environmental intention

Table 3. Pearson product moment correlation test

\begin{tabular}{llcc}
\hline & Model & Personal Responsibility & Pro-Env.Intention \\
\hline \multirow{2}{*}{ Personal Responsibility } & Pearson Correlation & 1 & $.202^{*}$ \\
& Sig.(2-tailed) & & .027 \\
& $\mathrm{~N}$ & 120 & 120 \\
\hline
\end{tabular}

Table 4. Determination coefficient $\left(R^{2}\right)$ test results

\begin{tabular}{ccc}
\hline Model & $\mathbf{R}$ & R Square \\
\hline 1 & $.202^{\mathrm{a}}$ & .041 \\
\hline a. Predictors: (Constant), Personal Responsibility & &
\end{tabular}

The calculation data obtained determinant coefficient value determination $\left(R^{2}\right)$ equal to 0.041 . These results indicated that the variable personal responsibility contributes to the students' pro-envirronmental intention of $4.1 \%$ while $95.9 \%$ is related to other factors.

Students who have a high personal responsibility can learned how to respect the rights and feelings of others, decide their own desires and the importance of being responsible. This results are relevant to those proposed by Ernst et al. (2015), Mergler and Shield, 2016), and Wray-Lake et al (2010) that students who have highe personal responsibility can develop sensitivity to others (including compassion, empathy and interpersonal skills) and the ability to apply learning throughout programs into wider life (eg schools, homes).

Students who have higher personal responsibility are able to become independent learners, able to play an active role in learning and their desires more responsibly. According to Mergler (2008); Mergler and Patton (2007); and Mergler and Shield (2016) students with higher personal responsibility are able to become confident individuals, more responsible and creative desires including the ability to make rational and informed decisions about their lives and accept responsibility for their actions.

Students who have a high personal responsibility can learn how to respect the rights and feelings of others, decide their own desires and the importance of being responsible. For example, when given responsibility for protecting the environment, students who have a high personal responsibility will keep the environment clean.

Personal responsibility to the environment is the belief of a student to fulfill obligations and reduce consequences by not blaming the circumstances of the actions he made on the environment so that the existence of a high personal responsibility within the student can increase pro-environmental intention. This 
results were also supported by the findings of Pan et al. (2018), who argued that personal responsibility for the environment had an influence on one's desires which had an effect on the behavior of the environment itself.

This integrative literature review has examined the literature available in educational research that focuses on the quantitative measurement of personal responsibility in participants from high school. Contributions to new knowledge have been made by examining the similarities and differences in quantitative definitions and measures of personal responsibility.

\section{CONCLUSION}

The results showed that there was a positive relationship between personal responsibility and proenvironmental intention. The results indicated that the variable personal responsibility contributes to the students' pro-envirronmental intention of $4.1 \%$ while $95.9 \%$ is related to other factors. Students who have a high personal responsibility have several advantages, namely (1) can learned how to respect the rights and feelings of others, decide their own desires and the importance of being responsible; (2) able to become independent learners, able to play an active role in learning and their desires more responsibly, and (3) can learn how to respect the rights and feelings of others, decide their own desires and the importance of being responsible.

As a growing sense of personal responsibility continues to be the focus of national education policy, it is important that research in this field be systematically built. Providing systematic empirical data about the role of personal responsibility in educational outcomes for students serves to guide educational policy meaningfully. Understanding the ways in which researchers explore the development of personal responsibility has been defined, conceptualized and measured its construction can explain the direction for future research.

\section{REFERENCES}

Anand, S. V. (2013). Global environmental issues. Open Access Scientefic Reports, 2(2), 1-9. doi: https:// doi.org/10.4172/scientificreports.632

Ashurst, P. R., Hargitt, R., \& Palmer, F. (2017). Environmental issues. In P. R. Ashurst, R. Hargitt, \& F. Palmer (Eds.), Soft drink and fruit juice problems solved (2nd Ed., pp. 195-199). Woodhead Publishing. doi: https://doi.org/10.1016/B978-0-08-100918-5.00012-6

Aunger, R., \& Curtis, V. (2016). Behaviour centred design: towards an applied science of behaviour change. Health Psychology Review, 10(4), 425-446. doi: https://doi.org/10.1080/17437199.2016.1219673

Bellard, C., Bertelsmeier, C., Leadley, P., Thuiller, W., \& Courchamp, F. (2014). Impacts of climate change on the future of biodiversity. Ecology Letters, 15(4), 365-377. doi: https://doi.org/10.1111/j.14610248.2011.01736.x.Impacts

Bennet, T. (2017). Creating a culture: How school leaders can optimise behaviour. UK Department for Education. London: Department for Education (DfE). Retrieved from http://search.ebscohost.com/ login. aspx?direct=true\&db=eric\&AN=ED574131\&site=ehost-live

Bornstein, M. H., Hahn, C.-S., \& Haynes, O. M. (2011). Maternal personality, parenting cognitions and parenting practices. Developmental Psychology, 47(3), 658-675. doi: https://doi.org/10.1037/a0023181

Boysen, P. G. (2013). Just culture: a foundation for balanced accountability and patient safety. The Ochsner Journal, 13(3), 400-406. Retrieved from http://www.ncbi.nlm.nih.gov/pubmed/24052772\%0Ahttp: //www. pubmedcentral.nih.gov/articlerender.fcgi?artid=PMC3776518

Bronfman, N. C., Cisternas, P. C., López-Vázquez, E., De la Maza, C., \& Oyanedel, J. C. (2015). Understanding attitudes and pro-environmental behaviors in a Chilean community. Sustainability, $7(10)$, 14133-14152. doi: https://doi.org/10.3390/su71014133

Curtis, D. J., Reid, N., \& Reeve, I. (2014). Towards ecological sustainability: Observations on the role of the arts. Surveys and Perspectives Integrating Environment \& Society, 7(1), 1-15. Retrieved from https:// sapiens.revues.org/1655

Dementiy, L. I., \& Grogoleva, O. Y. (2016). The structure of responsibility of preschool and primary school age children. In Procedia - Social and Behavioral Sciences (Vol. 233, pp. 372-376). doi: https://doi.org/ 10.1016/j.sbspro.2016.10.161

Ernst, J., Blood, N., \& Beery, T. (2015). Environmental action and student environmental leaders : exploring the influence of environmental attitudes, locus of control, and sense of personal responsibility. Environmental Education Research, 4622(September), 1-27. doi: https://doi.org/10.1080/13504622. 2015.1068278 
Fedele, G., Locatelli, B., Djoudi, H., \& Colloff, M. J. (2018). Reducing risks by transforming landscapes: Crossscale effects of land-use changes on ecosystem services. PLOS ONE, 13(4), 1-21. doi: https://doi.org/ 10.1371/journal.pone. 0195895

Harris, U. S. (2019). Participatory media in environmental communication: Engaging communities in the periphery (1st Ed.). New York, US: Routledge. Retrieved from https://www.crcpress.com/ParticipatoryMedia-in-Environmental-Communication-Engaging-Communities/Harris/p/book/9781138655287

Hasnat, G. N. T., Kabir, M. A., \& Hossain, M. A. (2018). Major environmental issues and problems of South Asia, Particularly Bangladesh. In C. M. Hussain (Ed.), Handbook of Environmental Materials Management (pp. 1-40). Switzerland: Springer Natrure. doi: https://doi.org/10.1007/978-3-319-585383_7-1

Hope, A. L. B., \& Jones, C. R. (2014). The impact of religious faith on attitudes to environmental issues and Carbon Capture and Storage (CCS) technologies: A mixed methods study. Technology in Society, 38, 48-59. doi: https://doi.org/10.1016/j.techsoc.2014.02.003

Johnson, K., Courser, M., Holder, H., Miller, B., Ogilvie, K., Moore, R., ... Saylor, B. (2007). A community prevention intervention to reduce youth from inhaling and ingesting harmful legal products. Journal of Drug Education, 37(3), 227-247. doi: https://doi.org/10.2190/de.37.3.b

Joshi, Y., \& Rahman, Z. (2015). Factors affecting green purchase behaviour and future research directions. International Strategic Management Review (Vol. 3). Holy Spirit University of Kaslik. doi: https://doi. org/10.1016/j.ism.2015.04.001

Kanianska, R. (2016). Agriculture and its impact on land-use, environment, and ecosystem services. In A. Almusaed (Ed.), Landscape ecology - The influences of land use and anthropogenic impacts of landscape creation (pp. 1-26). IntechOpen. doi: https://doi.org/10.5772/63719

Keshavarz, M., \& Karami, E. (2016). Farmers' pro-environmental behavior under drought: Application of protection motivation theory. Journal of Arid Environments, 127, 128-136. doi: https://doi.org/10.1016/ j.jaridenv.2015.11.010

Kinzig, A. P., Alston, L. J., Barrett, S., Nw, C. R., Levin, B., \& Levin, S. (2013). Social norms and global environmental challenges: The complex interaction of behaviors, values, and policy. Bioscience, 63(3), 164-175. doi: https://doi.org/10.1525/bio.2013.63.3.5.Social

Kollmuss, A., \& Agyeman, J. (2002). Mind the Gap: Why do people act environmentally and what are the barriers to pro-environmental behavior? Environmental Education Research, 8(3), 239-260. doi: https:/l doi.org/10.1080/13504620220145401

Manstead, A. S. R. (2018). The psychology of social class: How socioeconomic status impacts thought, feelings, and behaviour. British Journal of Social Psychology, 57(2), 267-291. doi: https://doi.org/10. $1111 /$ bjso. 12251

Martin, J.-L., Maris, V., \& Simberloff, D. S. (2016). The need to respect nature and its limits challenges society and conservation science. In Proceedings of the National Academy of Sciences (Vol. 113, pp. 61056112). doi: https://doi.org/10.1073/pnas. 1525003113

Mergler, A. (2008). Personal responsibility: The creation, implementation and evaluation of a school-based program. Queensland University of Technology. Retrieved from https://eprints.qut.edu.au/16382/

Mergler, A., \& Patton, W. (2007). Adolescents talking about personal responsibility. Journal of Student Wellbeing, 1(1), 57-70. doi: https://doi.org/10.21913/JSW.v1i1.113

Mergler, A., \& Shield, P. (2016). Development of the personal responsibility scale for adolescents. Journal of Adolescence, 51, 50-57. doi: https://doi.org/10.1016/j.adolescence.2016.05.011

Michie, S., West, R., Sheals, K., \& Godinho, C. A. (2018). Evaluating the effectiveness of behavior change techniques in health-related behavior: A scoping review of methods used. Translational Behavioral Medicine, 8(2), 212-224. doi: https://doi.org/10.1093/tbm/ibx019

Pan, S., Chou, J., Morrison, A. M., \& Lin, M. (2018). Will the future be greener? The environmental behavioral intentions of university tourism students. Sustainability, 10(634), 1-17. doi: https://doi.org/10.3390/ su10030634

Pickard, H. (2014). Responsibility without blame: Therapy, philosophy, law. Prison Service Journal, 213, 10 16. Retrieved from https://www.ncbi.nlm.nih.gov/pmc/articles/PMC4430804/

Rechkemmer, A., \& Von Falkenhayn, L. (2009). The human dimensions of global environmental change: Ecosystem services, resilience, and governance. In EPJ Web of Conferences (Vol. 1, pp. 3-17). EDP Sciences. doi: https://doi.org/10.1140/epjconf/e2009-00906-y

Sadhu, S. D., Garg, M., \& Kumar, A. (2018). Major environmental issues and new materials. In C. M. Hussain 
\& A. K. Mishra (Eds.), New polymer nanocomposites for environmental remediation (pp. 77-97). Elsevier. doi: https://doi.org/10.1016/B978-0-12-811033-1.00004-4

Seebacher, F., \& Franklin, C. E. (2012). Determining environmental causes of biological effects: The need for a mechanistic physiological dimension in conservation biology. Philosophical Transactions of the Royal Society B: Biological Sciences, 367(1596), 1607-1614. doi: https://doi.org/10.1098/rstb.2012.0036

Slavoljub, J., Dragica, G., Zorica, P. S., Zivkovic, L., \& Sladjana, A. (2015). To the environmental responsibility among students through developing their environmental values. In Procedia - Social and Behavioral Sciences (Vol. 171, pp. 317-322). doi: https://doi.org/10.1016/j.sbspro.2015.01.128

Steg, L., \& Vlek, C. A. J. (2007). Human behavior and environmental sustainability: Problems, driving forces, and research topics. Journal of Social Issues, 63(1), 1-19. doi: https://doi.org/10.1111/j.1540-4560. 2007.00493.x

Steg, L., \& Vlek, C. A. J. (2009). Encouraging pro-environmental behaviour: An integrative review and research agenda. Journal of Environmental Psychology, 29(3), 309-317. doi: https://doi.org/10.1016/j. jenvp.2008.10.004

United Nations Environment Programme. (2017). Towards a pollution-free planet. Nairobi, Kenya. Retrieved from https://wedocs.unep.org/bitstream/handle/20.500.11822/21800/UNEA_towardspollution_long versi on_Web.pdf?sequence=1\&isAllowed=y

Wray-Lake, L., Flanagan, C. a, \& Osgood, D. W. (2010). Examining trends in adolescent environmental attitudes, beliefs, and behaviors across three decades. Environment and Behavior, 42(1), 61-85. doi: https://doi.org/10.1177/0013916509335163.Examining

Zastrow, C., Kirst-Ashman, K. K., \& Hessenauer, S. L. (2019). Empowerment series: Understanding human behavior and the social environment (11th Ed.). Boston, MA.: Cengage Learning. Retrieved from https:/l www.cengage.co.uk/books/9781337556477/ 